\title{
Gypsies, ethnicity, and the labour market: An introduction
}

\author{
MARIA JOSÉ CASA-NOVA
}

The article reports on two years of ethnographic research carried out within a Gypsy community in an area on the outskirts of Porto, in northern Portugal. Data were collected during participating observation in labour environments (fairs) and residential settings (a council ward) as well as from interviews. The aim is to contribute to our knowledge and understanding of the lifestyle and opportunities of a particular community, in particular what employment means in this community and the relationship it establishes with the wider labour market. The data show (a) that capitalism of flexible accumulation affected the marginalized ethnic groups who live on the periphery of the system, and (b) that the relationship between a specific Portuguese Gypsy community and employment is mediated by ethnic belonging. Some crucial elements in the choice of occupation in this community are (a) independence through self-employment, which allows people to combine work with looking after the children and attention to intra-ethnic solidarity, and (b) the possibility of personal time management.

Keywords: Portuguese Gypsies, ethnography, kinship, social and political organisation, work, labour market, capitalism of flexible accumulation, ethnicity, ethnic habitus, cultural genetics, family socialization

\section{Introduction}

This article reports on lifestyles within a Gypsy community, with particular reference to how employment is perceived in the context of the changing labour market in the present-day 'capitalism of flexible accumulation' (Harvey 1989). We try to understand--in the Weberian sense of apprehending the meaning of social action'-(a) how the transformations in industrial organisation affect marginalised ethnic groups such as Gypsies, not just the main employed socioeconomic classes, and (b) what work means for a specific Gypsy community. To this end, we first carry out a basic background study of the community, followed by an analysis of the changes in industrial organisation and of the

I would like to thank two anonymous reviewers for their comments, which allowed me to improve the final version of this article. I also would like to thank the Fundação para a Ciència e a Tecnologia (Foundation for Science and Technology) for the financial support of this research.

Maria José Casa-Nova is Assistant Professor of the Sociology of Education in the Department of Sociology of Education and Educational Administration, Institute of Education and Psychology, University of Minho, Campus de Gualtar, 4710-Braga, Portugal. E-mail: mjcasanova@ iep.uminho.pt

Romani Studies 5, Vol. 17, No. 1 (2007), 103-123 1SSN 1528-0748 
meaning of employment. Essentially, the analysis will be carried out by studying the data collected during fieldwork and by earlier studies by the author (Casa-Nova 1992, 1999, 2002), addressing theoretical questions with regard to these issues.

\section{Background of the community}

The research of which this article is part was undertaken within five extended families with a common ancestry, comprising 52 nuclear relatives, amounting to 190 individuals whose ages range from 4 months to 85 years.

\subsection{Residence}

The families, like the majority of Portuguese Gypsies, are sedentary, residing in an area on the outskirts of Porto, in the north of Portugal. ${ }^{1}$ The majority of these nuclear units live individually in apartments, though cases of cohabitation in the same apartment of two, sometimes three, nuclear families exist-usually, parents with single children and a married daughter or son. However, this individualised lifestyle does not mean the dissolution of extended family bonds, which continue to exist intensely, independently of sharing the same physical space.

\subsection{Marriage, relationships, and endogamy}

Most of the families are endogamous (of the 52 unions, only eight are exogamous), in which people usually marry first cousins (siblings of a brother or a sister), or with slightly more distant relatives such as second-, third-, or fourthdegree cousins. ${ }^{2}$ Such relationships between bridal pairs were also shown in the studies that Sutherland (1975), Williams (1984), and San Román (1997) carried out within Gypsy communities.

Marriage between first cousins is favoured, not only as a form of reinforcing family ties (which was observed by Williams and San Román, too), but also as a way of guaranteeing that the siblings of sisters or brothers (through which they are considered to have an increased responsibility) will not be left on their own (i.e. without husband or wife).

The exogamous marriages in the community took place in three of the extended families studied, with six Gypsy men married to non-Gypsy women

\footnotetext{
1. In the south of Portugal and, to a lesser extent, near the northern border with Spain, there are Gypsy families who, though having a permanent residence, practise seasonal nomadism because of professional interests (going to fairs in certain parts of the country and participating, at certain times of the year, in the harvesting in Portugal or Spain).

2. Endogamous marriage is understood as marriage between two Gypsies. Exogamous marriage is taken to mean marriage between a Gypsy and a non-Gypsy. For a more complex approach to the endogamy-exogamy distinction, see Williams (1984: 267-9).
} 
and two Gypsy women married to non-Gypsy men. Exogamous marriages are not well received in the community; when they do occur, marriages of Gypsy men with pailhas (non-Gypsy women) are tolerated better than those of Gypsy women with pailhos (non-Gypsy men). ${ }^{3}$ This is the case partly because it is the woman who circulates among kinsfolk (she moves in with the husband's family; men move in with their wife's family only when his parents cannot support the new family member) and, since Gypsy communities are patrilinear, because the son of a Gypsy with a paitha is considered more of a Gypsy than the daughter of a Gypsy and a pailho.

In two of the studied extended families there is pressure (successful up to the present) to avoid exogamous marriages in order to maintain their Gypsy ethnicity and purity of 'race' and also because, as a young Gypsy girl mentioned to us, 'a man of your culture is another head' ('another head' meaning another rationality, another way to see the world).

Weddings last from three days to a week, proof of virginity of the bride being the high point of the ceremony. This test takes place at midnight on the first day, the moment when the bridal pair is considered to be husband and wife. A woman functions as the community's strength and weakness since the man's pride, honour, and disgrace reside in her. In effect, this makes her a hostage of the community: social control prevents her from attending school or anything else that does not constitute an extension of domestic life, such as fairs. ${ }^{4}$

\subsection{Language}

By default (among each other or with people outside their community), the community members express themselves in Portuguese. They switch to a particular dialect (a mixture of Portuguese, Caló, and Romanes) at moments of inter-ethnic tension (mainly with the police) or when they do not want to be understood by non-Gypsies. Their mastery of Romanes, however, is very restricted; only the older members of the community are proficient in their language, though even they have difficulty in establishing a dialogue in Romanes only. ${ }^{5}$

\footnotetext{
3. For a comparison with how marriages with non-Gypsies are viewed in England, France, and Spain, see Okely (1983), Williams (1984), and San Román (1997), respectively. As in Portugal, these studies show regularity among Gypsy communities from different countries in relation to the way of viewing marriage with non-Gypsies which is normally either prohibited or not very well received.

4. Some Gypsy giris manage to break the reproduction cycle, attending secondary schooling. However, there are no graduated Gypsy girls in Portugal from endogamous marriages. 5. Some Rornanes words used and that the community allowed the researcher to divulge are Busnó ('non-Gypsy'), Bori ('daughter in law', 'girl'), lacha ('shame'), lumia ('prostitule'), poguinó ('paid you'), and shuri ('pocket knife').
} 


\subsection{Religion}

Most Gypsies in our community belong to the Evangelical Church of Philadelphia and worship regularly. Catholics by tradition, Portuguese Gypsies gradually converted to the Evangelical Church of Philadelphia, mainly in the last fifteen years. This movement entered Portugal in around 1974 through two Spanish Gypsy ministers (see Sá 2001).

In the studied community, religion functions as a form of social regulation and of expression of what they call 'excessive Gypsy emotion', expressed at moments of intra- and inter-ethnic tension. The religious bond is heightened at those moments of tension when they can be heard to say 'they are taking advantage because they know we are God's Gypsies.'

In some families, religion also functions as a form of controlling expenses, offering financial discipline that has allowed some family groups to buy their own house. As a Gypsy woman said,

God is the one who has helped us. God is everything. God has helped us have discipline, be uncompromising. A Gypsy is a spendthrift. He spends almost everything on food. He doesn't know how to cook a small quantity of food and he wastes a lot. We would put money in the bank every week. It was how we managed to buy this house. (Gypsy woman, 28, married with two sons; fieldwork notes)

\subsection{Social and political organization}

The networks which our community establishes and maintains tend to be intraethnic. Reciprocity and solidarity in times of economic, social, and emotional fragility of its members are essential for the maintenance of group cohesion. ${ }^{6}$ A stingy Gypsy who accumulates wealth without sharing it with the others is viewed as an apayar, that is to say, someone who is becoming a non-Gypsy, deviating from the Gypsy spirit. This duty of sharing is in the first place restricted to close family (parents, brothers, sisters, nieces, nephews, uncles, grandparents, first cousins), and in the second instance to other types of relative and, finally, other Gypsies from the community or from others communities. Nevertheless, sharing is not always voluntary; it usually results from group pressure on the individual who shares in order to avoid exclusion from the community and in order to establish reciprocity at moments of individual fragility. However, a Gypsy who shares his material goods ensures that his social and symbolic

6. In his research with Hungarian Gypsies, Stewart (1997: 89) speaks of an 'ethos of sharing' as a "fundamental aspect of the "Gypsy way". From our research, we consider that this 'ethos of sharing' has, as a basis, among other aspects, a defence and a protection facing non-Gypsies; it is constructed and measured in and through the relationships with that. In relation to sharing see also Formoso (1986). In this research, the families studied by Formoso referred to the prodigality and the solidarity existing among Gypsies as a non-existent practice among the non-Gypsies, thereby considering it as an element of superiority in relation to the gadjé. 
capital is increased in the group, his generosity contributing to his intra-ethnic standing, which in turn enhances not only his personal prestige but also that of the family.

Many of the community members live under tension between the desire for a certain individualism and the desire for group protection when facing a non-Gypsy who is mistrusted and who excludes them (Casa-Nova 2004). ${ }^{7}$ Experience and community-sharing function as a form of group protection and strengthening vis-à-vis the outside world; they are conditioned by the relationships with and the perception of non-Gypsies, thus contributing to the construction of relatively well-defined ethnic boundaries (Barth 1970), resulting in differentiated (and modifiable) levels of social integration.

Rather than function with a single leader, as is the tradition, the community functions with various leaders: older men in the community who are considered sensible and wise. This body constitutes a Gypsy court which tries to solve the community's problems-the Kris. The court is made up of Gypsies of the community and, when necessary, also by Gypsies of other communities residing in other parts of the country.

Though Gypsies answer to the law of the Portuguese state, any Gypsy who commits a crime of blood or of honour in the community is judged twice. After serving the state's sentence, he will then be tried by the community and suffer the revenge of the offended person's or the dead victim's family, which affect not only him, but all members of his extended family. The severity of any revenge is determined by the strength of the targeted family, which is measured by the number of family members and each member's wealth. Thus, revenge varies from situation to situation. In two cases of revenge that involved two of the studied extended families, the extended families were bigger in one case and was wealthier in the other case, so the extended families were not affected, though the nuclear families had to move away. Even though several members of this community condemn revenge when it targets the members of the aggressor's family and not only the aggressor, they continue to exercise it due to group pressure; a Gypsy who does not avenge his honour is ostracized by the community.

\subsection{Nationality, ethnicity, and perception of self}

Though the studied families are descendants of Gypsies who have lived in Portugal for centuries and though all their members have Portuguese nationality, in daily relations with non-Gypsy Portuguese they frequently refer to 'you, the Portuguese' and 'we, the Gypsies. When confronted by the researcher with the fact they are also Portuguese citizens, they say, 'Oh, you know what we mean;

7. For group protection among Gypsy groups from other countries, see, among others, Okely (1983) and Stewart (1997). 
sure, we're Portuguese, but we're Gypsies. We are Gypsies and Portuguese.' This means that, in a relationship with a non-Gypsy, ethnicity takes precedence over nationality; the same situation does not happen when they face Gypsies from other countries, such as immigrant Romanian Gypsies. Here, it is the feeling of national belonging that comes in first place, often referring to them in a pejorative way, 'They are Gypsies, but not Portuguese like us.'

\subsection{Levels of schooling}

Data collected in these families reveal a population with very low levels of schooling compared with the general Portuguese population. Of a total of 190 individuals (of which 34 are under 6), the two members with a higher level of schooling are attending the tenth and ninth grade (two boys of 17 ). Among the members who do not now attend school, one has completed the eighth grade, one has the seventh grade, 21 (with ages between 14 and 32) have the sixth grade (of which only one is a woman), two members finished the fifth grade (one woman), 49 completed the fourth grade ( 33 of these are aged from 14 to 30 ), 23 attended school from the first till the third grade ( 15 of which ared aged between 31 and 50 ), and 17 never attended school. Of these 17 , nine are between 41 and 50 , four between 21 and 30 . Among children of obligatory school age (6-15), of a total of 38 persons, six (aged between 11 and 15) have already abandoned the school system. This means that of 124 individuals older than 6 who do not attend school, 39.5 per cent have completed the fourth grade (the first four years of schooling), 18.5 per cent attended school from the first and third grade, and 13.7 per cent have never attended school-this in a population in which only eleven people are over $50{ }^{8}$

\subsection{Profession}

Very few Gypsies in this community have attended courses for professional training and those who did, do not have a profession compatible with that training. Many think that this is because of the racism of the Portuguese nonGypsies towards Gypsies. But in the participating observation we carried out we could see that, besides this racism, other factors-low wage levels, the existence of supervision, seven hours of daily work done in closed spaces-create a situation in which they seek alternatives for their professional lives. However, there are courses that teach knowledge that can be used profitably, namely, IT courses. The skills acquired in these courses enable the use of computers and the internet to download films and create illegal DVDs.

8. The total number individuals does not include the partners resulting from exogamous marriages. Despite being from disadvantaged social classes, their school levels are comparatively higher: between the seventh and tenth year. 
In professional terms, and like the majority of Portuguese Gypsies, the members of this community dedicate themselves mostly to selling clothes (some to selling shoes) in specifically alloted spaces such as fairs; in the last three years they have also started to sell counterfeit DVDs as a way of diversifying and to get around the effects of 'capitalism of flexible accumulation' (Harvey 1989). ${ }^{9}$ This is the type of work that they think they have a talent for, since they feel they are persuasive talkers capable of convincing non-Gypsies. This was also observed by Stewart (1994) in his work with Hungarian Gypsies. According to various members of the community observed by us, 'there is nobody that can sell more than Gypsies can.'

\section{Gypsies and the labour market: Some general remarks}

The Gypsy communities have resided in Portugal since the sixteenth century (cf. Costa 1995$)^{10}$ and mainly do independent unpaid work, though throughout the years, the types of activity have varied. From fortune-tellers to circus actors and mule sellers, from basket makers to junk dealers, from part-time farm hands to peddlers-nowadays mainly fair hawkers-the occupations of Portuguese Gypsies, have developed a common characteristic: they are selfemployed, autonomous, and flexible, so that they can easily adapt to changes in their environment. ${ }^{11}$ This has been noted in studies on Gypsies carried out by diverse researchers in different countries (see Acton 1974; Sutherland 1975; San Román 1976, 2002; Okely 1983; Williams 1984; Formoso 1986 and Stewart 1994, among others). Nevertheless, in the 1980s the Portuguese Gypsies maintained a certain professional stability, a characteristic of a Fordist regime and the paradigm of modernity, reconfigured by the transition to a regime of flexible accumulation of capital. According to David Harvey (1989: 147),

Flexible accumulation . . . is marked by a direct confrontation with the rigidities of Fordism. It rests on flexibility with respect to labour processes, labour markets, products and patterns of consumption, [appears to] imply relatively high levels of 'structural' (as opposed to 'frictional') unemployment, rapid destruction and reconstruction of skills, modest (if any) gains in the real wage.

Which means that

9. Some of them dedicate themselves to illicit activities, such as selling drugs.

10. According to Costa, the first documented reference dates from 1510 , being part of the Cancioneiro Geral by Garcia de Resende. In 1521, the second reference emerges in the Farsa das Ciganas by Gil Vicente. But, through the description that the author gives of Gypsy customs, it appears that Gypsy presence in Portuguese society is even older.

11. As Stewart said (1997: 84-5), As anyone who has carried out serious research among Gypsies will teil you, they continue to find economic and social niches in which to make a living and maintain their way of life.' 
The labour market... [has] undergone a radical restructuring. Faced with strong market volatility, heightened competition and narrowing profit margins, employers have taken advantage of weakened union power and the pools of surplus (unemployed or underemployed) labourers to push for much more flexible work regimes and labour contracts [originating an] apparent move away from regular employment towards increasing reliance upon part-time, temporary or sub-contracted work arrangements. (Harvey 1992: 150)

Indeed, in spite of not being employed, ${ }^{12}$ and, therefore, not being in an employee-employer relationship, 'the transition from Fordism to flexible accumulation' that Harvey mentioned implied diverse problems for the Portuguese Gypsy communities. These problems are related to what seems to be the impossibility of maintaining some stability and security in a certain relatively informal market segment (fairs), which they could do up until the mid-198os; until then, they managed to sell certain types of articles of clothing and shoes at non-competitive prices.

\subsection{Gypsies and the labour market: results of a specific research}

From the 1990s, the studied community saw the problems outlined in the previous section get worse as profit margins decreased and their niche market became less secure. This is the result of the diminishing of buying power of the more disadvantaged Portuguese because of increasing unemployment rates and the general volatility of the labour market and by the increasing competition of the Asian countries whose populations have immigrated to Portugal, competing to an extent with the Gypsies for the same market segment. In the words of some members of the studied community:

This is utter misery. People do not have money for buying things. Factories close, people become unemployed, wages are low (bosses pay very little because they know that there are many unemployed and they play with that), and we are the ones who bear the brunt. Even selling cheaper, we sell very little. We sell less. (Gypsy man, 44; fieldwork notes)

Before-ten, fifteen years ago-business was more profitable. Now there is more competition from the Asian people who can manufacture with cheaper workers and profit is lower because one must sell cheaper. (Gypsy man, 56; fieldwork notes)

Up to more or less ten years ago, Gypsies stocked up in factories and warehouses. With the arrival of the Asian people, of the Chinese, who sell very cheap, a Gypsy began to gain less. Nowadays many Gypsies even stock up with the Chinese. (Interview extract of one of the leaders of the community)

12. There are Gypsies in Portugal in salaried jobs, for example, mediators between school and the Gypsy community, drivers, and security guards, but they are few and are often not supervised. 
Because they [the Chinese] are even supplying shops ... and everything. Now, everyone goes there to buy. Most factories, small factories from here, are closing. I see that every day in the newspaper; factories are all closing. (Gypsy man, 56 years; interview extract).

The Chinese are ruining our economy. It's true! The factories where Gypsies and other fair hawkers get supplies, they can't compete with the Chinese, with their prices. They are all going bankrupt! There's only unemployment! I don't know how they can manufacture so cheaply! I don't know! They must work for free and their Government also helps them. And here, our Government, it doesn't help us, but theirs does. Did you know that, for five years, they don't pay taxes? And, do you know what they do? When the five years are up, they close that warehouse and they open another one in their wife's name or their brother-in-law's and they are allowed five more years! It's really something! (Gypsy man, 42; fieldwork notes)

These quotations show that their jobs are not secure, which puts at risk the economic survival of this community and other Portuguese Gypsy communities, since they try to remain competitive by reducing their profit margins. The quotations also show that the Gypsies feel that various types of immigration further weaken an already precarious labour market. The rise in unemployment rates; the increase of part-time work (as opposed to full-time employment) and subcontracting; employment without a work-contracts-all these are factors they think contribute to the general weakening of their way of life.

\subsection{Market societies, flexibility, and employment uncertainty}

The competitiveness of today's market societies (which increases with globalization) leads to changes in the labour market, of professions, and of careers: the valorization of flexibility, expressed in the accumulation of skills that should be transformable facing new and renewed needs, promotes the disappearance of the individual as a person, through the elimination of his aspirations and needs in favour of the needs of the market. 'The flexible individual, from the point of view of the labour market, is the one that is reprogrammable facing the demands of that market' (Casa-Nova 2003: 255). This flexibility is the fundamental condition for the individuals to be considered 'employable' beings (see Magalhães and Stoer 2002). In this socio-economic context, 'the individual gradually becomes an object of successive secondary socializations, structuring a flexible secondary habitus, a generator of adjustable dispositions towards the demands of the market, where precariousness appears as a fundamental dimension of work experience at the end of the twentieth century and the beginning of the twenty-first century' (Casa-Nova 2003). And, as Bourdieu (2000: 148) says, the 'establishment of a condition of generalized and permanent precariousness' becomes part of 'a form of domination of a new type... with the objective of forcing workers to submit and to accept exploitation.' 


\subsection{Diversity of strategies and economic survival}

We must, however, note the existence, in some populations, of the formation of a primary habitus that follows in the sense of constructing a 'cultural mind' (Iturra: 1990) permeable to the acceptance of precariousness and flexibility in the labour market, making the daily construction of survival strategies possible. Gypsies can be considered an example of this, as they show a degree of occupational flexibility that makes them-apparently, at least-sensitive, vulnerable, and at the same time adaptable to markets, forms and processes of work inherent to new forms of organization of the accumulation regime and the mode of social and political regulation associated with it' (Harvey 1989: 121).

Used to living, both through the need and due to specific socio-historicalcultural constraints, ${ }^{13}$ in an informal economy, a large part of the Portuguese Gypsy ethnic minority appears as particularly vulnerable to new forms of capitalist exploitation and accumulation of capital. Thus, we can begin to understand why various adult male members of the studied community have developed strategies of occupational diversity, in what seems simultaneously to constitute a form of maintaining their freedom and a form of economic profitability. Indeed, some members of this community (their number changes along with fluctuations in the market) have taken jobs such as of security guards in building construction, working without any contract and without any supervision. This means that they can easily walk away from those jobs, though they can also be fired without any hassle on their employers's part. On the positive side, this type of job allows them to take their women and other family members to fairs, go back home for some sleep, go back to the fairs again after a little rest, thus combining two jobs, which are combined with yet another type of income, namely, that from welfare: Social Income of Insertion (which replaced the Minimum Guaranteed Income). ${ }^{14}$ Those two jobs are not taxed; the first job because there is no contract, and any tax payable on the second type of job is simply evaded.

Without national insurance the community members are vulnerable as they cannot claim unemployment benefits and are not eligible for any pension. This

13. Compare the constant occupational change of Gypsies throughout time, adapting either to the disappearance of traditional occupations or to new socio-cultural contexts and realities. 14. As far as this commmunity is concerned, it must be stressed that it tries to develop strategies that make it possible to take the maximum advantage of the marginalization process in which it exists, namely, through fear that they provoke in others (that, constituting symbolic capital, allows them to enjoy, in the quarter where they live, housing, water and electricity without paying) and through knowledge of certain legislative measures (for example, the mechanisms of the attribution of the Social Income of Insertion), that allows them to take advantage of state institutions by claiming benefits. 
vulnerability is mitigated to an extent, on the one hand, by networks of family and community solidarity and, on the other hand, by unemployment benefits or a pensions which, as they are not sufficient, have to be supplemented by the network provided by the community.

As we saw above, some capitalist forms admit and demand the realization of precarious work for the accumulation of capital. Without actually involving payment of wages, this allow for the economic survival for some groups within the Gypsy community. This structural flexibility explains at least in part the community's occupational adaptability within a specific segment of the market (selling in fairs), and the development of another type of precarious work offered by new forms of organization of the capitalist accumulation regime. Thus, the socio-cultural marginalization of the community is turned into an advantage, the only way to survive in the absence of high levels of schooling and professional qualifications. Outside the traditional field of Gypsy occupation, the Portuguese Gypsy communities share uncertain jobs, low social status, and low wages with other generally disadvantaged groups.

\section{Gypsies and meaning of employment}

As mentioned at the beginning of this article, and corroborating work done by other authors (see references mentioned earlier), most Portuguese Gypsies never developed paid employment, and, thus, never formed any kind of relationship with employers (this state of affairs is not restricted to Gypsies in Portugal). Because of this they often appear as lazy in the eyes of the outside world, presenting a 'negative social representation' of the Gypsy communities (Duarte et al. 2005). Of the ethnic and immigrant minorities in Portugal, the non-Gypsy Portuguese are more biased against the ethnic minorities. However, like Gypsies in other countries, Portuguese Gypsies' attitude to work is that it should fullfil certain basic needs-having a job in itself carries no prestige.

We work in order to eat, to give food to our children. (Gypsy woman, 31; fieldwork notes)

We have to eat, don't we? Therefore, we have to work! (Gypsy man, 28; fieldwork notes)

In the community in which our field research was carried out, as in other researched communities in the country (see Antunes 1997 and Fernandes 1999), members engage mainly in selling clothing and shoes in allotted spaces (such as fairs), developing, sometimes, and as we mentioned earlier, additional activities when the domestic economy demands this. 


\subsection{Professional negative aspects}

\subsubsection{Economic insecurity}

The nature of work that is carried out by the community members allows them to organise their employment as they see fit, though their occupational autonomy. This allows them much freedom-such as moving to other fairs in search of more customers-but is also a weakness in that their future is uncertain. As was frequently mentioned during the realization of the fieldwork,

We choose the fairs that we consider the best. Normally, we do three fairs a week and the other two days are for buying supplies. But, we work many hours. Normally, when we do fairs, we work for around fifteen hours a day. (Gypsy man, 36; fieldwork notes)

And also, the money we earn isn't always the same. There are weeks that we get really very little. [.. . . It's this way: up to September, sometimes, up to the middle of October, we do business. From the middle of October to the end of November, we hardly get anything. Then, up to Christmas, we do business. Then, from January to the middle of April, we, again, hardly do business. Starting from then, up to the Summer, business is usually good. We earn some months to cover the others. ${ }^{15}$

\subsubsection{Unfavourableness}

A profession like this, however, implies some sacrifices, namely, having to get up very early and being subjected to intemperate weather. This, combined with the unpredictability of their earnings, is considered the most negative side by the community members.

Then, the bad weather in winter and in summer and having to get up, sometimes, at four, five in the morning. For me, these are the most negative aspects. And also, who works twelve, fifteen hours a day? There are days when we really work these hours! (Gypsy man, 56; fieldwork notes )

These negative aspects lead some members of the younger generation to start looking for different kinds of work, not only as an alternative to a kind of life which today seems economically precarious, but also as a way to improve their social status. But in this they are often frustrated by racist attitudes in society ('differentialist racism', as Wieviorka 1995 calls it).

I would like to do something else, but even if I had, say, more education, they wouldn't give me a job. They know you are a Gypsy, bingo! They don't give you a job. (Gypsy man, 30; fieldwork notes) 
The change in the type of work appears to be connected to the development of another type of activity, one that helps maintain an independent status in the face of the authorities:

the authorities, or a company, whatever, have their rules, which are not the rules of the community [... .] they [the Gypsies] are not able to accept the rules imposed by a certain entity of power. They want their independence and, therefore, we are trying, even in the neighbourhood, to see whether we manage to go forward with the idea of creating self-employment, which is different from the job of fair hawker. [...] the idea was, the idea is, rather, to create in the neighbourhood, because, in the neighbourhood, there are various young people with professional training courses, and, for example, almost a type of cooperative of work, say, take an auto mechanic, a sheet metal worker, an auto painter, an auto electrician, and, all together, they would open a company, like, we would create a garage and the person who would take his car to that garage would know that, from an electrician to painting, everything he wanted done would be done in that garage. [...] this would be so, first, to substitute the non-opening of the labour market to the community, and as an alternative to the fairs that, at the present time, are not being sufficient factors, ways of survival for the members of this neighbourhood. [On the other hand] because the young people, that already have ideas on some aspects which are perfectly different from their parents', from their grandparents' [...], know what a sacrifice a fair is [...] get up at three in the morning to do a fair, for example, in Espinho $[\ldots]$ the people of the neighbourhood that will rapidly manage to really create a garage have the need to feel, how can I explain this to you, to say with another type of pride 'I'm a Gypsy and I am a car mechanic'. (Extract of an interview of a member of the community with an elevated prestige within it).

We stress here that it is not only the uncertainty of their traditional life style that makes Gypsies want to change their occupations, but also the low social prestige of their lifestyle.

\subsection{Professional positive aspects}

\subsubsection{The realization of independent work as 'cultural genetics'}

The data that we have collected suggest that the change of professional life, mentioned in the previous section, is mainly viewed in terms of developing an independent professional style as self-employed, showing an 'ethnic habitus' that overlaps with a 'class habitus' (see Casa-Nova 19.99, 2002, 2005), and appears as 'cultural genetics', structuring certain socio-cultural practices (with regard to the established relationship with the labour market). As we mentioned in previous work (see Casa-Nova 1999, 2002, 2005), the ethnic habitus is constructed during the processes of primary socialization in family education greatly influenced by ethnicity and the intra-ethnic relationships of sociability between children and adults and is defined, not by the possession of economic capital, but, on the other hand, on a basis of an important homogeneity in what 
lifestyles and opportunities are concerned, having a certain 'philosophy of life' behind it. This philosophy conditions their ways of acting, moulded by a common and transversal ethos in relation to which the behaviour and attitudes of this community are widely defined, regarding, namely, the cultural capital in its institutionalized state (Bourdieu 1998) and the institution of school and also the labour systems of the greater society' (Casa-Nova 1999: 35). This ethnic habitus

is incorportated from childhood through the observation of practices, body language, and discourse productions of adults and the exteriorization of daily cultural practices; these are responsible for the lifestyles and opportunities of the members of this community, conditioning their social and cultural practices independent of their class belonging, since the cultural determination overlaps the economic determination in the structuring of the habitus.' (Casa-Nova 2005: 208)

Occupational independence is the most stressed positive aspect in relation to the work they do:

The most positive aspect is being independent, not having anyone bossing us. In spite of the negative aspects, I wouldrit change my profession. (Gypsy man, 36; fieldwork notes)

The most positive aspect is being free, being independent, not having a boss. That is the most important. (Gypsy man, 56; fieldwork notes)

Freedom, not having a boss, a fixed schedule. If I want to come later, I do, if I want to leave earlier, I do. If I don't want to come to work, I don't. Of course, I lose money. But, we have that freedom. (Gypsy man, 28; fieldwork notes)

If you ask all the Gypsies in this fair, all of them will say the same: the best of all this is not having a boss. The boss is us. (Gypsy man, 28; fieldwork notes)

For many members of our community, being self-employed is something that 'derives from earlier':

Well, all this, practically, already comes from before, isn't it?, from the other generations [...] since our parents, our grandparents, etc.. It was always, it always fell upon this kind of work [. . .] because, usually, [the Gypsies] do not like being bossed very much, isn't that so? Our being our own bosses already comes from antiquity. It is in our blood. (Gypsy man, 56 years; interview extract and fieldwork notes).

A Gypsy doesn't like to work with a boss. It was always like this. He doesn't like to be ordered around. It is how he is. It has always been like this." (Gypsy woman, 44; fieldwork notes)

\subsubsection{Simultaneous education of children}

The women also refer, as a positive aspect, to the fact that this type of work enables them to keep their children with them all the time: 
This profession is good because we can bring our children, be around them. (Gypsy woman, 26; fieldwork notes)

Being a fair hawker on our own account allows us to be around our children, which is a good thing. I have Rita [the oldest daughter], but, if I didn't have her, and I had another kind of work, where would I leave her? (Gypsy woman, 33; fieldwork notes)

Time spent working, therefore, is also a time of socialization, of spending time with family and the community, and time spent educating the children and young people, all of which amounts to intra-ethnic sociability. Family, work, and sociability seem to criss-cross in a complex web of apparently undifferentiated relationships and functions, but which, in fact, are just gradually differentiated. This means that understanding the processes of exclusion, insertion, and integration of these communities involves understanding, not only their direct relationship with material production and with the world of work, but also how these groups "live" and "construct" their lives; that is, with their processes of "social reproduction" and of "cultural production"' (Stoer 1994: 8).

\subsubsection{Solidarity in illness}

According to various members of the community, being self-employed has the added advantage that ill family members can be looked after:

If I have a family member in the hospital or ill at home, you know, I can go visit them or stay at home with them. We have that freedom. And, also, we are confident that some family member will remain in the fair if needed. (Gypsy woman, 44; fieldwork notes)

If I had work like yours, how could I not work for so long and be able to accompany my father? Me and my sisters? In this way, I can leave the stall to my nieces or to my cousins and be able to stay with him in the hospital. Or, if I want to, not come to work. (Gypsy woman, 38; fieldwork notes)

\subsubsection{Intra-ethnic solidarity at moments of inter-ethnic tension}

Self-employment is also perceived as offering a certain ethnic protection in relations with non-Gypsies. Even if the existing threat is only symbolic, the proximity of 'ethnic sameness' contributes to their psychological comfort.

And, this type of work allows us to work near each other. This is good for business and for protecting one another: on the one hand, in this way, people immediately come to the part of the fair where the Gypsies are (they know it is where they buy things cheaper); on the other hand, we are near one another and, if anything is needed (with the police or anything), we protect one another, of course! If Gypsies didn't protect themselves, who would? We're a minority! (Gypsy man, 56; fieldwork notes) 


\subsubsection{The construction of a professional habitus}

Children and young people learn about professions during everyday life at fairs, through observation (and sometimes imitation) of the roles of their parents and other adults. This usually limits their work prospects to this type of profession. Children are taken to fairs by their parents and are thus socialized professionally on a daily basis. They help their parents set up and take down the stalls and sell the exhibited articles from the age of five, gradually incorporating a professional habitus which, according to the members of the community, is an integrated part of their way of being a Gypsy.

This life of selling is in the Gypsy. It's ours. We sell like nobody else. We know how to sell. It's being a Gypsy. It always has been. (Gypsy man, 52; fieldwork notes)

I don't know how to do anything else. It was what I learned. I have come, since I was small, to the fairs with my mother. But, there are young boys that get married and they don't even know how to do it. Because they don't want to know. And then, the women sell." (Gypsy young male, 18; fieldwork notes)

When a new family is formed, the parents offer the newly wed a place in the fairs and buy them their first merchandise. In this way the young couple are given a good start in their professional lives, as it happens with the children in more advantaged families (but in the case of Gypsies, conditioned by ethnic belonging and the constraints of mainstream society; see Casa-Nova 2004).

As a way of guiding young people towards another type of occupation, some members of these communities consider withdrawing the children from the fairs altogether:

Since I am now old, for me, there is no alternative. I tried to make it different for my children, but they didn't want that and they are all fair hawkers. But this depends on education. I hope that with their children it will be different. But for that to happen you have to educate them from early childhood, to take away the idea of fairs from them, to put them in school and not bring them to the fairs. They get used to them and, then, they want to be fair hawkers. It is necessary to take away that idea from them and that is done by educating them from childhood." (Gypsy man, 56; fieldwork notes)

When my Tiago was small, I didn't have anyone to leave him with and I brought him to the fairs. But, then, I stopped bringing him. Coming to the fairs, they get used to this and, then, they don't want anything else. They like to wander in the fairs, they get used to this life and, then, it is difficult to change. Since I wanted another kind of life for my Tiago, I stopped bringing him. (Gypsy woman, 44, with a son attending tenth grade).

Nevertheless, there are very few Gypsies in this community who think like this. Most continue to take the children to fairs, even at school age, making successful schooling impossible because of high absenteeism, though they say that it is not a lack of confidence in schooling and in the professionals that work there: 
It is not a lack of confidence in them, we are the ones who get worried about whether they are all right, if they are not all right. Or having to go get the child at six. We have to leave the fair at five. (Gypsy man, 46 years. Interview extract).

The case of having a family and children: we have to give attention to our children. It's not for me, for my wife or for anyone [...] to have a child in a nursery, this, it is, we are against those things. With family, we know, in our opinion, that they are safe. (Gypsy man, 56; interview extract).

This type of behaviour not only makes successful schooling impracticable and limits their children's professional options, it also results in a socialization, from a very young age, that is centred around this type of occupation, leading to the construction of a primary habitus. In this way, the ethnic characteristics end up conditioning the Gypsies' occupation; and the fixation on this type of occupation (as fair hawkers) contributes to perpetuating the cultural characteristics of the community. In sum, our research shows that Gypsies consider work as a way to survive (the instrumental side of work), though they find their independence satisfying (personal/professional realization of work). Thus, some things which they consider more important than work, and which they consider as 'part of being a Gypsy'-in other words, their ethos-are:

(a) being self-employed has the following advantages:

- there is no employer, so they are independent and answer to no-one;

- they can combine work and looking after the children as they take the children to work;

- group solidarity ensures that other Gypsies help and protect them in any conflicts with non-Gypsies.

(b) time management

- they are not bound to office hours, they can decide when they work;

- they can choose their own working days, picking the best days at possibly different markets;

- through group and family solidarity they are supported in crises;

- they have sufficient time for family and friends and to participate in social events of the community.

In spite of the transition from a Fordist regime to a flexible accumulation regime, which makes the traditional professional activity of the Gypsy community precarious, the Gypsies continue to consider it as the most viable way of life given their present-day levels of schooling and professional training. However, they are beginning to realise the need for higher levels of schooling, which will allow new generations to develop more prestigious professions; at the same time, they maintain their independence and continue the professional lifestyle that enables this independence and all the cultural values that they 
consider fundamental. This contributes to their feeling of superiority in relation to the outside world which, in their opinion, does not hold the same types of values-family and group cohesion; the commitment to and care of children and the elderly; solidarity and reciprocity in illness; solidarity and reciprocity at moments of inter-ethnic tension. Thus, the type of habitus that they develop allows them to reproduce-though with changing configurations-family and group cohesion and the values that they consider essential for their survival as an ethnic group.

\section{Social classes, ethnicity, and the value of work}

In relation to the value of work, it is interesting to note that the Gypsies share some of the appreciation of professional characteristics with certain segments of the more privileged social classes. In fact, in the non-Gypsy social classes, studies carried out in various countries (Portugal, Spain, Hungary, Germany, and Sweden) on relationships within the labour market show that the type of work that is valued more and more is that which permits personal time management and allows individuals leisure time and the time and space for family and friends (Freire 2000; Ramos 2000; Vala 2000). This is very much the Gypsy perspective on work. In other words, some of the upper segments of the non-Gypsy population value work in the same way that Gypsies do; Gypsies and these population segments are close in the way in which they consider the value of work, showing post-materialistic values (Inglehart 1970), and emphasising the importance of personal expression, participation, and quality of life. These observations agree with the data on Gypsy family socialization and education collected in my research: many Gypsy parents in the observed families value their children's education (though not always consciously), as well as the attribution of self, autonomy and curiosity, security and responsibility. It is interesting to note that in non-Gypsy society, this attitude is more common in families in the privileged social classes than in socially disadvantaged families (Lobrot 1962; Gecas 1979; Lautrey 1985; Kellerhals and Montandon 1991). This contributes to the 'low permeability to cultural assimilation' (Casa-Nova 2005: 212) that Gypsies have demonstrated throughout their precense in Portuguese society. ${ }^{16}$

Contrary to what the same studies verified in the education of children of disadvantaged social classes (which show more authoritative and coercive practices), when Gypsy children demonstrate behaviour that is considered to be unsuitable, their parents prefer to explain to the children why their behav-

16. In this article I try to understand the Gypsies' low degree of cultural assimilation throughout its presence in Portuguesc society and the importance of family socialization and education in this process. 
iour is unacceptable rather than punish them physically. These results are also in agreement with the work of Formoso $(1986,1994)$ and Smith $(1997)$ with Gypsy families, where the authors refer to the near absence of physical punishment among the observed Gypsies and the importance of persuasion.

\section{Some final reflections}

Transformations in the organization of industrial production with the consequent capitalist industrialization led to what Lenhardt and Offe (1984) desribed as 'passive proletarization', the gradual destruction of the conditions of use of a labour force. According to Lenhardt and Offe, passive proletarization takes place when individuals can no longer use their work as a basis of their subsistence, since they lose control over the conditions of its use. ${ }^{17}$

Though the studied Gypsy community (and the other Portuguese Gypsy communities) do not take part in passive proletarization since they do not constitute wage-earning groups, transformations in the organisation of industrial production, with the consequent increase in unemployment rates, the increase of the working day in certain cases, part-time work and job uncertainty, result in the degradation of the material conditions of existence of these communities. Being part of the productive process in the commercialisation phase of certain products, the Gypsies of this community-and Portuguese Gypsies in general-see their economic way of life and their conditions of survival affected, on the one hand, by the diminishing of the buying power of those who traditionally buy their products and, on the other hand, by the competition from Chinese immigrants. These immigrants, the Gypsies think, manage to sell the same products at non-competitive prices because of the conditions offered by the Chinese and the Portuguese states and by the low wages paid by Chinese businessmen; in addition, the Chinese workers have longer working days.

Although these factors contribute to the degradation of the conditions of the studied Gypsies, they try to counter their effects by reducing their profit margins, through the diversification of their merchandise, and the search for supplementary means of subsistence. They do this while trying to maintain the.work conditions that allow them to hang on to their independence, which is fundamental for their ways of life and their ethos. Defying the inherent presuppositions of present-day capitalism and flexible accumulation, Gypsy forms of work demonstrate that other ways of organising employment are possible-namely, employment schemes that do not include the accumulation of wealth, alienation, and hierarchy through work, or in other words: the separation of various aspects of life.

17. See Cortesão, Stoer, Casa-Nova, and Trindade (2005). 


\section{References}

Acton, Thomas. 1974. Gypsy politics and social change. London; Routledge and Kegan Paul.

Antunes, Adelino. 1997. Os príncipes do nada-contributo para o estudo de um trabalho social de Reinserção de populaçōes ciganas. Coimbra: Edição da associação Integrar.

Barth, Fredrik. 1970. Ethnic groups and boundaries. London: Allen \& Unwin.

Bourdieu, Pierre. 1998. Os três estados do capital, In Escritos de Educação. Maria Alice Nogueira and Afrânio Catâni, eds. Pp. 71-9. Petrópolis: Editora Vozes (zrd edn).

-2000. Una utopia razonada: contra el fatalismo económico. New Left Review (o): 156-62;

Casa-Nova, Maria José. 1992. A cultura Cigana e a socializaçăo do género femininosubsídios para o seu conhecimento. Lisbon: JNICT.

- 1999. Etnicidade, género e escolaridade-estudo em torno das socializaçöes familiares de género numa comunidade cigana de um bairro periférico da cidade do Porto. Dissertation, Faculdade de Psicologia e de Ciências da Educação, Porto.

-2002. Etnicidade, género e escolaridade: Estudo em torno das socializações familiares de género numa comunidade cigana da cidade do Porto. Lisbon: IIE.

-2003. Ciganos, escola e mercado de trabalho. Revista Galego-Portuguesa de Psicoloxia e Educación 8(10): 252-68.

-2004. Gypsy culture, children, schooling and life opportunities. In Between diversity and inequality: Children's experiences of life and school in multicultural Europe. Silvia Carrasco, ed. Nueva Colección Urban Chilhood research monographs, 1 (see http://www.cimu.org).

-2005. Etnicidade e educação familiar: $O$ caso dos ciganos. Revista Teoria e Prática da Educaçāo, Brasil (Maringá/-Paraná) 8(2): $207-14$.

Cortesão, Luiza, Stephen Ronald Stoer, Maria José Casa-Nova and Rui Trindade. 2005. Pontes para outras viagens. Escola e comunidade cigana: representaçöes recíprocas. Lisbon: ACIME.

Costa, Eduardo Maia. 1995. Os ciganos em Portugal: Breve história de uma exclusão. In $\mathrm{O}$ povo cigano: Cidadāos na sombra. Luiza Cortesão and Fátima Pinto, eds. Pp. 13-2o. Porto: Ediçōes Afrontamento.

Duarte, Isabel, Joana Afonso, Maria José Lobo Antunes, Alexandra Castro, Margarida Salgueiro, and Mafalda Sousa. 2005. Coexistência inter-étnica, espaços e representações sociais: Os ciganos vistos pelos outros. Lisbon: ACIME.

Fernandes, Teresa. 1999. Comunidade cigana em Beja: Traços culturais e problemática da escolarização. Dissertation, Faculdade de Cièncias Sociais e Humanas, Lisbon.

Formoso, Bernard. 1986. Tsiganes et sedentaires: La reproduction culturelle d'une societé. Paris: L'Harmattan.

— 1994. Diversité des itinéraires et uniformité des stéréotipes. Revue études Tsiganes 2: $127^{-38}$.

Freire, João. 2000. Orientaçōes sobre modelos de trabalho e percepçōes sobre condiçōes sociais, técnicas e económicas do trabalho. In Trabalho e cidadania. Manuel Villaverde Cabral, Jorge Vala, and Joāo Freire, eds. Pp. 15-45. Lisbon: ICS. 
Gecas, Viktor. 1979. The influence of social class on socilization. In Contemporary theories about family, vol. i. W. R. Burr, F. I. Hill, and I. Reiss, eds. Pp. 365-404. New York: Free Press.

Harvey, David. 1989. The condition of postmodernity. Blackwell: Oxford: Blackwell. Inglehart, Ronald. 1970. The silent revolution. Princeton: Princeton University Press. Iturra, Raul. 1990. A construçāo social do insucesso escolar. Lisbon: Editora Escher.

Kellerhals, Jean and Cléopâtre Montandon. 1991. Les styles éducatives. In La famille: L'état des savoirs. F. Singly, ed. Pp. 195-201. Paris: Ed. La Decouverte.

Lautrey, Jacques. 1985. Clase social, medio familiar e inteligencia. Madrid: Visor.

Lobrot, Michel. 1962. Sociologie des attitudes éducatives. Enfance 1: 69-83.

Lenhardt, Gero and Claus Offe. 1984. Teoria do estado e política social. In Problemas Estruturais do Estado Capitalista. Clauss Off, ed. Pp. 10-53. Rio de Janeiro: Tempo Brasileiro.

Magalhāes, António, and Stephen Ronald Stoer. 2002. A nova classe média e a reconfiguração do mandato endereçado ao sistema educativo. Educaçāo, Sociedade \& Culturas 18: 25-40.

Okely, Judith. 1983. The Traveller-Gypsies. Cambridge: Cambridge University Press.

Ramos, Alice. 20oo. Centralidade do trabalho. In Trabalho e cidadania. Manuel Villaverde Cabral, Jorge Vala, and João Freire, eds. Pp. 47-69. Lisbon: ICS.

Sá, Joaquim de Abreu. 20ol. In Que sorte, Ciganos na nossa escola! Secretariado Entreculturas/Centre de recherches tsiganes, ed. Lisbon: Interface. Pp. 249-50.

San Román, Teresa. 1976. Vecinos Gitanos. Madrid: AKAL.

-1997. La diferencia inquietante. Madrid: Siglo Veintiuno de España Editores.

—2002. Los Gitanos en el mundo del trabajo. La Mirada Límpia 9: 34-46.

Smith, Tracy. 1997. Recognising difference: The Romani 'Gypsy' child socialisation and education process. British Journal of Sociology of Education 18(2): 243-56.

Stewart, Michael. 1994. Fils du marché, les maquignons tsiganes et le modèle anthropologique. Revue études Tsiganes 2: 105-26.

-1997. The puzzle of Roma persistence: Group identity without a nation. In Romani culture and Gypsy identity. Thomas Acton and Gary Mundy, eds. Pp. 84-98. Hertforshire: University of Hertforshire.

Stoer, Stephen Ronald. 1994. Construindo a escola democrática através do campo da recontextualização pedagógica. Educação, Sociedade \& Culturas 1: 7-27.

Sutherland, Ann. 1975. Gypsies: The hidden americans. London: Tavistock.

Vala, Jorge. 20oo. Mudanças nos valores associados ao trabalho e satisfação com o trabalho. In Trabalho e cidadania. Manuel Villaverde Cabral, Jorge Vala, and João

- Freire, eds. Pp. 71-95. Lisbon: ICS.

Wieviorka, Michel. 1995. Racismo e modernidade. Venda Nova: Bertrand Editora.

Williarns, Patrick. 1984. Mariage Tsigane. Une cérémonie de fiançailles chez les Rom de Paris. Paris: L'Harmattan/Selaf. 
CASA-NOVA, Maria José (2007). Gypsies, ethnicity, and the labour market: An introduction. Romani Studies 5, Vol. 17, № 1, pp. 103-123. 